
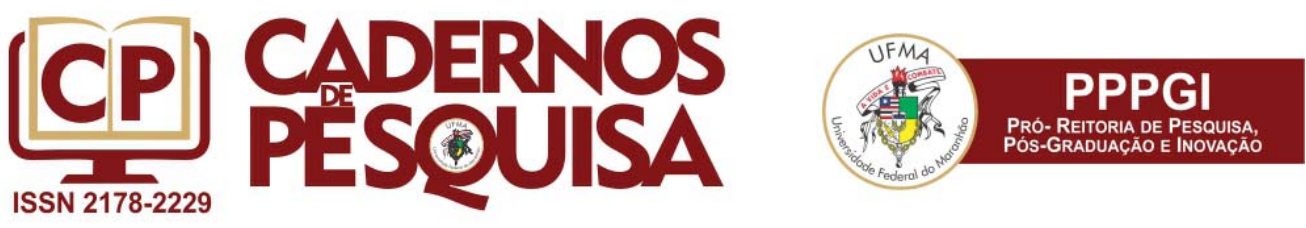

\title{
A CIDADE COMO CAMPO DA EDUCAÇÃO NÃO FORMAL E AS EXPERIÊNCIAS DAS CRIANÇAS
}

\author{
THE CITY AS A FIELD OF NON-FORMAL EDUCATION \\ AND THE EXPERIENCES OF CHILDREN
LA CIUDAD COMO CAMPO DE LA EDUCACIÓN NO FORMAL Y LAS EXPERIENCIAS DE LOS NIÑOS

\author{
Renata Sieiro Fernandes \\ Professora Doutora do Centro Universitário Salesiano de São Paulo (UNISAL). \\ São Paulo-SP, Brasil. \\ renata.fernandes@unisal.br \\ Antonio Carlos Miranda \\ Professora Doutora do Centro Universitário Salesiano de São Paulo (UNISAL). \\ São Paulo-SP, Brasil. \\ antonio.miranda@unisal.br \\ Irene Quintáns \\ Diretora e Curadora da Red OCARA. \\ São Paulo-SP, Brasil. \\ redocara@gmail.com
}

\section{Resumo}

Parte-se da ideia da cidade como campo da educação não formal. Dentre os usos e ocupações atuais do espaço público por contestação, manifestação, lazer, sob orientações políticas, étnicas, artísticas, ambientais, lúdicas, pelo público adulto, têm surgido experiências que envolvem as crianças, como sujeitoscidadãos ativos e participativos na cidade, o que vem a constituir a experiência da cidade. O objetivo é apresentar e discutir aspectos educativos no campo da educação não formal que são desenvolvidos por meio de ações sociais e comunitárias, relacionando com o conceito de currículo e de currículo oculto no espaço da cidade. Metodologicamente, é um estudo exploratório, de abordagem qualitativa no campo da Educação, do tipo bibliográfico e documental e descritivo e analítico quanto aos seus objetivos. Parte do levantamento de práticas nacionais de educação não formal na cidade envolvendo crianças, tendo sido selecionados 5 projetos dentro de duas categorias denominadas projetos de revitalização do espaço público e projetos de escuta das crianças, para discussão. O referencial teórico baseia-se em Trilla, Sennett, Lefebvre e outros. Os dados mostram que, na ocupação dos espaços públicos, o currículo deixa de ser prescrito para ser construído pelas comunidades, na promoção das oportunidades de acesso aos bens sociais e culturais nas três dimensões em que a cidade educa: aprender da cidade, aprender na cidade, aprender a cidade. As crianças que participam dos projetos são entendidas como sujeitos sociais e públicos e que produzem cultura (não apenas a reiteram), promovendo processos de criação, reinvenção e modificação do entorno, do que é comum, das comunidades e da sociedade. Conclui-se que essa participação e as ações empreendidas dão margem a novas possibilidades de atuação no mundo, tirando os sujeitos das tiranias da intimidade.

Palavras-chave: Educação não formal. Cidade educativa. Educação e cultura. Currículo.

\begin{abstract}
This article starts with the idea of the city as a place of non-formal education. Among the current uses and occupations of the public space for contestation, demonstration, leisure, under political, ethnic, artistic, environmental and playful orientations by the adult public, experiences have arisen that involve children as active and participative citizen subjects in the city. This is what constitutes the experience of the city. The objective is to present and discuss educational aspects in the field of non-formal education that are developed through social and community actions, relating to the concept of curriculum and hidden curriculum
\end{abstract}

Artigo recebido em outubro 2017. Aprovado em novembro de 2018. 
in the universe of the city. Methodologically, it is an exploratory study, qualitative approach in the field of Education, bibliographic and documentary type and descriptive and analytical about its objectives. Part of the survey of national practices of non-formal education in the city involving children, 5 projects were selected within two categories called projects of revitalization of public space and projects of listening to children, for discussion. The theoretical framework is based on Trilla, Sennett, Lefebvre and others. The data show that, in the occupation of public spaces, the curriculum is no longer prescribed to be built by the communities, in promoting opportunities for access to social and cultural goods in the three dimensions in which the city educates: learning from the city, learning in the city , learn the city. The children who participate in the projects are understood as social and public subjects and that produce culture (not only reiterate it), promoting processes of creation, reinvention and modification of the environment, of what is common, of communities and of society. It is concluded that this participation and the actions undertaken give rise to new possibilities of action in the world, taking the subjects from the tyrannies of intimacy.

Keywords: Non-formal education. Educational city. Education and culture. Curriculum.

\section{Resumen}

Se parte de la idea de la ciudad como lugar de educación no formal. En el caso de los niños, como sujetos ciudadanos activos y participativos en la ciudad, entre los usos y ocupaciones actuales del espacio público por contestación, manifestación, ocio, bajo orientaciones políticas, étnicas, artísticas, ambientales, lúdicas, por el público adulto, han surgido experiencias que involucran a los niños, lo que viene a constituir la experiencia de la ciudad. El objetivo es presentar y discutir aspectos educativos en el campo de la educación no formales que se desarrollan a través de acciones sociales y comunitarias, relacionándose con el concepto de currículo y de currículo oculto en el universo de la ciudad. Metodológicamente, es un estudio exploratorio, de abordaje cualitativo en el campo de la Educación, del tipo bibliográfico y documental y descriptivo y analítico en cuanto a sus objetivos. Parte del levantamiento de prácticas nacionales de educación no formal en la ciudad que involucra a niños, se seleccionaron 5 proyectos dentro de dos categorías denominadas proyectos de revitalización del espacio público y proyectos de escucha de los niños, para discusión. El referencial teórico se basa en Trilla, Sennett, Lefebvre y otros. Los datos muestran que, en la ocupación de los espacios públicos, el currículo deja de ser prescrito para ser construido por las comunidades, en la promoción de las oportunidades de acceso a los bienes sociales y culturales en las tres dimensiones en que la ciudad educa: aprender de la ciudad, aprender en la ciudad, aprender la ciudad. Los niños que participan en los proyectos son entendidos como sujetos sociales y públicos y que producen cultura (no sólo la reiteran), promoviendo procesos de creación, reinvención y modificación del entorno, de lo que es común, de las comunidades y de la sociedad. Se concluye que esa participación y las acciones emprendidas dan lugar a nuevas posibilidades de actuación en el mundo, sacando a los sujetos de las tiranías de la intimidad.

Palabras clave: Educación no formal. Ciudad educativa. Educación y cultura. Currículo.

\section{INTRODUÇÃO}

O desassossego é uma enfermidade da identidade que tem a ver com a alma e com a relação que temos com o tempo. A inquietude, contudo, começa no cérebro e mina nossa relação com o espaço, destruindo sua familiaridade e suas certezas, e convertendo-o em asfixiante. Os místicos e os poetas cultivam o desassossego. Mas a inquietude pertence, sobretudo, às crianças e aos viajantes.

(LARROSA, 2015, p. 104-105).

O tema deste artigo é a cidade como campo de educação não formal, ideia-força defendida por Trilla (1999; TRILLA, 1997) e o objetivo é apresentar e discutir aspectos educativos no campo da educação não formal que são desenvolvidos por meio de ações sociais e comunitárias, relacionando-os ao conceito de currículo e de currículo oculto no espaço da cidade (TRILLA, 1999).

A justificativa centra-se em entender a cidade como espaço e como lugar de educação, de forma institucionalizada ou não, e vê-la como campo de educação tanto informal quanto não formal, focando na ideia de currículo que perpassa as experiências formativas dos sujeitos na cidade, especialmente as crianças, já que elas carregam em si o desassossego e a inquietude que é própria de quem não se enquadra no que está dado e que busca linhas de fuga e escape ao estabelecido hierarquicamente. 
Entendendo a Educação como um campo de conhecimento (reflexivo e prático), que trata da formação, da socialização, da humanização e da subjetivação (CHARLOT, 2010 , p. 151) dos sujeitos e grupos sociais visando a construção de uma proposta societária (mantendo-a ou transformando-a), pode-se localizar, didaticamente, dentro do campo da Educação, o informal, o não formal e o formal.

Tomando um percurso histórico, a educação formal é a última que surge, pois esta se atrela as instituições educativas escolares, que têm a atribuição de ensinar às gerações os conhecimentos elencados como sendo úteis e necessários para a sociedade. A educação não formal e a informal são anteriores e mais abrangentes em termos de estrutura, organização, tempos-espaços, se perpetuam e persistem.

\begin{abstract}
Rogers usa a imagem do iceberg ao falar desses contextos educacionais, explicando que a parte visível na superfície e a que se refere a educação formal; a outra parte, ainda visível, mas mais próxima a água é mais abrangente que a anterior, e a que corresponde a educação não formal; e a parte invisível, submersa, de maior amplitude e base para as outras partes, é a que se simboliza a educação informal. Portanto, todas estão interligadas (ROGERS, 2004 apud FERNANDES, 2016, p. 127).
\end{abstract}

De forma genérica, para Trilla $(1997,1999)$ pode-se assumir que a educação formal é aquela institucionalizada, sistematizada, com intencionalidade e que acontece nos tempos-espaços escolares, visando, especialmente, o ensino e tem como órgão regulador e normatizador, no Brasil, o Ministério da Educação (MEC). Portanto, para o autor, toda educação formal é escolar e vice-versa e, vale a pena mencionar que, para Faria (2005), o termo não-escolar pode ser adequado ao se referir à Educação Infantil, que faz parte do sistema de ensino formal/escolar brasileiro, como etapa da Educação básica, a partir da Nova Lei de Diretrizes e Bases da Educação Nacional (LDBEN), de 1996, no nosso país, mas que, por tentativa de construção identitária, deva se diferenciar das características aprisionantes e capturadoras do modelo ou forma escolar, cujo foco é o ensino enquanto ela defende o foco na educação.

A educação não formal acontece dentro de instituições, mas também fora delas, nos agrupamentos humanos, sob a forma de movimentos, manifestações, especialmente nos espaços da cidade e promovem processos de aprendizagem. Comporta a intencionalidade e a sistematização como características intrínsecas e não está sujeita à normatização e regulação pela via de algum órgão centralizador.

Aeducação informal se caracteriza por experiências não intencionais ou incidentais, dentro do contexto de vivência individual, familiar e social e acontece permanentemente (TRILLA, 1999).

Tomando a ideia de campo, a educação formal e a não formal constituem-se como sendo autônomos e independentes (GARCIA, 2015), embora estabeleçam relações e conexões. Entretanto, um não se define em função do outro, contendo características e especificidades próprias, ainda que possam se interpenetrar em algumas ocasiões e situações. Desta forma, acabam complementando-se e contribuindo para a construção do percurso formativo dos sujeitos e dos grupos sociais. O campo da educação informal permeia esses dois.

Fica, então, evidenciado que opta-se pelo conceito de campo [a partir do entendimento da filosofia deleuziana, apontada por Garcia (2015)] para evidenciar as diferenças entre os termos e não a ideia de forma (pelo entendimento linguístico), já que esta está presente em qualquer fenômeno. Para Trilla (1997, 1999), subentende-se que o termo forma ou formal se refere à normatização ou elaboração e implementação de conteúdos, meios, técnicas, formas de avaliação, por um órgão regulador.

Ainda que a educação formal, escolar tenha surgido posteriormente, é sabido e notório que a forma escolar se amplia e se propaga, tendendo a configurar os modos pelos quais as práticas e os processos educativos acontecem, tanto na metodologia quanto em sua terminologia. Entretanto, não é possível generalizar que essa forma 
circunscreva de modo abrangente e totalitário as práticas, especialmente as que envolvem a interconexão entre Educação e cultura, ainda que tente se consolidar de modo hegemônico.

Sendo assim, é possível criar e encontrar modos contra-hegemônicos ou de resistência de produção de saberes e ações no cotidiano, que ocorram dentro, mas também fora de instituições, que tenham como foco pensar e agir na e sobre a cidade. Logo, que partam da preocupação do uso e ocupação do espaço público como o lócus e do sujeito público como o agente das ações.

Como a formação dos sujeitos e dos grupos sociais se dá na coletividade, contribui para a construção e o exercício do sujeito público, no sentido daquele que pensa e age politicamente fora das "tiranias da intimidade" (SENNETT, 1988). E, ainda, tem o aprender como processo que acontece para além daquilo que se deseja, se planeja, se institui de forma generalizada e intencional, de modo compartilhado e a partir da experiência singular e pessoal.

Atualmente, percebe-se um recrudescimento nos usos e compartilhamento dos espaços públicos urbanos ainda que persista um afastamento ou declínio da população (desde os anos 1970) em razão de um discurso midiático e uma sensação difusa - ou não - de violência e de casos de repressão policial, como formas do Estado manter o controle sobre seus cidadãos (BAUMAN, 2009).

Sennett (1988), nos anos 1970, apontava para o confinamento dos sujeitos nos espaços privados e internos (domiciliares e familiares), como efeitos do capitalismo e da ascensão da burguesia, havendo o declínio do homem público. Para ele,

[...] mas que tipo de personalidade se desenvolve através das experiências da intimidade? Uma tal personalidade se moldará na expectativa, se não na experiência, da confiança, do afeto, do conforto. Como pode ela ser suficientemente vigorosa para se movimentar num mundo fundado na injustiça? Será verdadeiramente humano propor a seres humanos a máxima de que suas personalidades "se desenvolvem", que eles se tornam "mais ricos" emocionalmente, na medida em que aprendam a confiar, a ser abertos, a partilhar, a evitar a manipulação dos outros, a evitar os desafios agressivos para obter condições sociais, ou a minar essas condições para proveito pessoal? Será humano formar eus brandos para um mundo áspero? Como resultado do imenso temor diante da vida pública que atacou o século passado, resulta hoje um senso enfraquecido de vontade humana (SENNETT, 1988, p. 319).

O reuso do espaço público se percebe, atualmente, pelas manifestações e movimentos populares em muitos lugares do Brasil e do mundo contestando as políticas dirigentes e econômicas capitalistas neoliberais impostas, como "forma de expressar revolta, indignação e protesto (ROLNIK, 2013, p. 10), com "[...] uma mesma forma de ação: ocupações de praças, uso de redes de comunicação alternativas e articulações políticas que recusavam o espaço institucional tradicional" (CARNEIRO, 2012, p. 8). Modos de ação contra hegemônicos ou de resistência.

Qual a conexão entre o movimento no Brasil e outros tantos do planeta, como o que ocorreu ao mesmo tempo em Istambul, a Primavera Árabe, o Occupy Wall Street, os Indignados da Espanha? Esses movimentos transformaram da praça Tahrir, no Egito, à praça do Sol, em Madri, da praça Syntagma, na Grécia, ao parque Zuccotti, nos Estados Unidos, passando pela praça Taksim, na Turquia, em palcos de protestos majoritariamente compostos por jovens, convocados por meio de redes sociais, sem a presença de partidos, sindicatos e organizações de massa tradicionais (ROLNIK, 2013, p. 11).

As insurreições, surgidas desde 2008, são exemplo de um despertar coletivo,

Raramente teremos visto, como nestes últimos anos, num lapso de tempo tão condensado, tantas sedes do poder oficial tomadas de assalto, desde a Grécia até a Islândia. Ocupar praças bem no centro das cidades e aí montar tendas, e aí montar 
barricadas, cantinas ou barraquinhas, e aí reunir assembleias, tornar-se-á em breve um reflexo político elementar como ontem foi a greve (COMITÊ INVISÍVEL, 2015, p. 9).

Mesquita (2011) também apresenta um levantamento e estudo da arte ativista e de ações coletivas no espaço urbano surgidas, especialmente nos anos de 1990 e 2000, a partir da experiência do protesto, da insurgência, de "uma cultura de oposição dentro das tramas cognitivas do capitalismo flexível” (p. 142).

Ao lado disso, também se pode perceber a apropriação da cidade como o lugar do encontro, da festa, do lúdico, em direção ao que preconizava Lefebvre (1991), já nos anos 1960, de reivindicação do direito à cidade como direito à vida, como lugar de encontro e vivência coletiva e compartilhada, de exercício da diferença e do múltiplo, que o sistema capitalista tenta capturar e controlar ao massificar. São exemplos disso, em São Paulo: a) o projeto Rios \& Ruas, que promove o reconhecimento e a exploração in loco da cidade redescobrindo a natureza de rios soterrados por ruas e construções visando uma compreensão afetiva sobre o uso do espaço urbano, b) a iniciativa do Buraco da Minhoca no túnel que passa embaixo da Praça Roosevelt, impedindo o acesso noturno aos carros e promovendo festas com dança, canto e música abertas a qualquer pessoa que queira participar, c) o movimento A Batata Precisa de Você, formado por moradores e frequentadores do Largo da Batata e pessoas dispostas a transformá-lo em um espaço de estar e não apenas de passagem, pendurando redes, realizando piqueniques e fazendo reuniões.

\title{
Harvey (2012), retomando a ideia de Lefebvre (1991), reforça que
}

\begin{abstract}
A questão de que tipo de cidade queremos não pode ser divorciada do tipo de laços sociais, relação com a natureza, estilos de vida, tecnologias e valores estéticos desejamos. O direito à cidade está muito longe da liberdade individual de acesso a recursos urbanos: é o direito de mudar a nós mesmos pela mudança da cidade. Além disso, é um direito comum antes de individual já que esta transformação depende inevitavelmente do exercício de um poder coletivo de moldar o processo de urbanização. A liberdade de construir e reconstruir a cidade e a nós mesmos é, como procuro argumentar, um dos mais preciosos e negligenciados direitos humanos ( $p$. 74).
\end{abstract}

E ressalta essa necessidade e exercício como modos de desafiar "a hegemonia liberal e a lógica de mercado neoliberal ou o modo dominante de legalidade e ação estatal" (HARVEY, 2012, p. 73).

Com Sennett (1988), Lefebvre (1991) e as ações que são sendo postas em prática pelos agrupamentos humanos, pode-se pensar na importância da experiência na cidade como algo que constitui o sujeito cidadão na contemporaneidade, indicando, inclusive, que esta problemática de enfrentamento persiste no tempo.

Não se pretende neste artigo apresentar programas que visam formatar e articular meios e instituições que se ocupem de educar na cidade, pois que se corre o alto risco de pedagogizar também o que não está capturado ou o que foge a captura, como bem analisam Vieira e Aquino (2015).

Em concordância com esses autores afirma-se que a ideia de uma educação que se prolonga no tempo e que se amplia pelos espaços, para além do formal/escolar, nem é nova e tampouco carece de inspirações liberais e de formas estendidas de exercício de poder, controle, normatização não apenas pelo Estado, mas também pelo terceiro setor e por iniciativa de organismos exteriores (como o Banco Mundial e a UNESCO para - Programa Cidade Educadora, inclusive em prática em algumas cidades do Brasil, por exemplo: São Paulo, Santo André, Horizonte, Mauá, Embu, Belo Horizonte, Sorocaba, São Carlos, entre outras) ${ }^{1}$.

Conforme consta do site <http://cidadeseducadoras.org.br/conceito/>. Acesso em: 10 set. 2017. 
Na crítica pertinente que fazem os autores, "[...] parece-nos inquestionável que a experiência urbana contemporânea, em sua totalidade e em suas minúcias, encontrará aí sua sagração como fonte e, ao mesmo tempo, alvo de intervenção pedagógica" (VIEIRA; AQUINO, 2015, p. 320). Entretanto, sem menosprezá-la e desconsiderá-la, o que se busca apresentar são as brechas ou as lacunas por onde algo ocorre de forma instituinte, resistente, assumindo as qualidades do bem público e do sujeito público, no sentido político, e também, de uma educação que se dê no e para o "mundo", na interação e tensão entre o particular e o público. E esse terreno é o da cultura e o das ações educativas que participam reiterando, ressignificando ou modificando as experiências.

Toma-se Trilla (1999) e algumas ferramentas conceituais e terminológicas que o autor apresenta, ainda que extraídas ou apropriadas do/pelo contexto formal/escolar para se pensar a educação não formal acontecendo no espaço da cidade e as brechas e lacunas tomadas ou provocadas por organizações da população e os coletivos que participam da construção do espaço urbano.

Aquele autor apresenta a ideia da cidade ou da sociedade que educa a partir de três dimensões, como: a) meio (aprender na cidade, por meio de instituições educativas ou potencialmente educativas, rede de equipamentos, acontecimentos efêmeros e ocasionais), b) como agente (aprender da cidade, por meio de socialização e formação a partir de aspectos culturais aleatórios, dispersos, não hierarquizados epistemologicamente) e c) como conteúdo/repertório (aprender a cidade, por meio do conhecimento de seu funcionamento, suas regras, seus usos possíveis).

Em pesquisa anterior (MIRANDA; FERNANDES, 2014), sobre as memórias de infância vividas na cidade e no campo, os depoentes dão indicativos de como aprendem nas três dimensões apresentadas por Trilla (1999), ou seja, na, da e a cidade:

Reconhecem que a cidade educa e como educa, ou seja, por meio institucionalizados educativos ou potencialmente educativos, como escolas - meio formal -, museus, bibliotecas, parques, jardins, zoológicos, centros culturais e casas de cultura, organizações de bairro - meios não formais, unindo educação à cultura, à arte, à política, à saúde etc. E por meios não institucionalizados, ou seja, pelas participações ativas ou não em manifestações ou mobilizações políticas, artísticas ou culturais; pela observação das paisagens visuais e sonoras; pelo patrimônio histórico e arquitetônico, pelos monumentos e obras de arte espalhados no tecido urbano; pelas placas de orientação, localização e sinalização que funcionam ora como mapas (para se saber onde está) ora como labirintos (para se deixar perder); pelos modelos de urbanização, uso do solo e do transporte motorizado e individualizado ou coletivo; pelo cuidado de si ao se precaver contra possíveis acidentes e ao atentar para a preservação da vida; pelo cuidado ao bem público; por meio de eventos públicos e palestras; pelos discursos verbais e imagéticos, pelo linguajar peculiar dos grupos sociais, pelas gírias - que comunicam ou são inteligíveis. A cidade educa e os sujeitos educam a cidade, ou seja, ao se inscreverem nela com repertórios culturais, sociais, étnicos e de gênero. Educam pelas festas comunitárias em que costumes e tradições são mantidos ou recriados, pela música, comida, dança etc; pelos encontros casuais e fortuitos e pelos planejados e intencionados; educa o corpo nas quadras de esportes e de ginástica, nos "carteados", a ter estratégia e saber lidar com frustrações e ganhos, nos brinquedos e jogos nas praças, a saber, estar junto e necessitar do outro. A cidade apresenta aos sujeitos suas diferenças sociais, culturais, históricas, e as desigualdades econômicas com diferenciação de qualidade nos produtos oferecidos aos grupos sociais e, daí, educa os sujeitos ao respeito ao outro e as diferenças, ao compartilhar, ao socializar. Educa os sujeitos para sentirem, perceberem e lidarem com as tensões e lutas de poder entre os fortes e os fracos, entre os que impõem normas e meios instituídos e aqueles que os burlam e reinventam as normas e meios. (MIRANDA; FERNANDES, 2014, p. 78)

A cidade como meio, educa, socializa, humaniza e subjetiva (CHARLOT, 2010) os sujeitos e os agrupamentos sociais que, assim, aprendem a partir de sua rede de 
equipamentos e serviços. Como agente, educa pela diversidade e na diferença, a partir das relações sociais que permite. Como conteúdo de aprendizagem, proporciona construir representações simbólicas do que é a dinâmica e a complexidade da cidade e o viver nela de forma participativa e ativa.

Quando trata da cidade como agente educativo, o autor traz a ideia de currículo e de currículo oculto que se opera no espaço e no tecido urbano, entendendo aquilo que se pretende, que se planeja, que visa ser atingido de modo explícito e implícito. Entretanto, ele considera que, "quando se trata aqui de 'currículo' o fazemos em um sentido figurado: já foi dito que não se trata de converter a cidade numa escola" (TRILLA, 1999 , p. 218, tradução nossa).

Desta forma, tomando o contexto apresentado até aqui e a proposição deste autor,

[...] Todas as cidades, muito ou pouco, bem ou mal, educam. E elas educam não só nas escolas e em outros determinados agentes educacionais, mas na medida em que a cidade - cada cidade - constitui uma estrutura, um sistema. E já se sabe que um sistema é sempre mais do que a soma de seus elementos. Portanto, as cidades, todas as cidades, educam e educam como um todo (TRILLA, 1997, p. 18, tradução nossa).

O currículo oficial e o currículo oculto são entendidos pelo autor como:

[...] A cidade, cada cidade, como agente educacional também tem, de certo modo, seu currículo, seu plano de estudos. Diríamos que tem seu próprio "currículo escondido", embora neste caso geralmente seja muito visível. Este currículo implícito da cidade é o conjunto contraditório formado pelo que nos transmite: elementos da cultura, modos de vida, normas e atitudes sociais, valores, tradições, costumes, expectativas, desejos [...] Tudo o que aprendemos diretamente através de dos modelos de comportamento presentes na cidade e das relações sociais que ela molda (TRILLA, 1997, p. 29, tradução nossa).

O sentido etimológico da palavra currículo, antes de ser cooptado pelo campo escolar, refere-se à ação (corrida), ao lugar (aonde se corre), ao percurso, aos parceiros e/ou adversários (com quem se corre) e à experiência (o que se passa em quem e enquanto se corre), ou seja, aquilo que se passa em um tempo e em um lugar delimitado. Disso decorre o aprendizado e os sentidos construídos sobre si, sobre os outros e sobre o mundo.

A partir deste conceito de currículo, percebe-se que há sentidos intuídos e há sentidos construídos, para além ou paralelamente ao que é estabelecido previamente, senão, não é possível haver experiência pessoal e singular. Entende-se, ainda, que o conceito não implica neutralidade, sendo campo de tensão de sentidos e significados (SILVA, 2010; SILVA, 1999).

É a partir do século XVII que o termo passa a ser associado ao contexto formal/ escolar, designando o que se devia estudar, a divisão por disciplinas, a sequenciação, o método, a estrutura, a organização por alguém que se coloca na posição de conhecedor, logo, em uma relação hierárquica de saber-poder via o controle dos fins (o que se devia aprender, logo, aonde se devia chegar e alcançar) (SILVA, 2010; SILVA, 1999).

Se o currículo se organiza desta forma na instituição escolar é porque ele se entrelaça à estrutura social e cultural mais ampla, portanto, a ideia de currículo extravasa (da escola para além dela) bem como incorpora (a sociedade hegemônica no interior da escola e da forma escolar) (GOMES; VIEIRA, 2009).

Silva (2010, p. 10) entende que o "currículo está no centro da relação educativa", sendo o espaço de tensão e de luta por significados culturais, que implica nos modos como os sujeitos e grupos sociais se formam e se socializam, constroem saberes e desenvolvem poderes por meio de práticas hegemônicas ou contra hegemônicas, produzindo resistência, identidades e diferenças. 
Para o autor, a concepção de currículo se baseia na noção de cultura essencialmente dinâmica. No caso da cidade, isto é válido pensar, já que nela estão dispostos conteúdos, discursos, imagens, ações, relações sociais de que tomam parte os sujeitos e os grupos sociais, produzindo, desmontando e desconstruindo o que é percebido pelos sentidos e reelaborado pelo pensamento e, também, remontando e reconstruindo sentidos e significados, em contextos de negociação, conflito e poder.

$E$, assim, fazem-se sujeitos da e na cidade em "incessante construção" (SILVA, 2010, p. 25), sem determinação, sem certezas, sem previsões, com ambiguidade, com contradição. Para Silva (2010, p. 27), "o currículo produz e o currículo nos produz".

A educação é prática social e pessoal, de criação e recriação de modos de ser e estar, por meio da qual os sujeitos conhecem a si, ao outro e ao mundo, simbolicamente, interpretando-os e comunicando-se, valendo-se de tentativas e esforços sensoriais, afetivos, cognitivos e de linguagens. O sujeito da experiência, então, constitui-se no espaço em que os acontecimentos têm e ocupam lugar. O sujeito da experiência é aquele que se expõe.

Segundo Larrosa (2015), a educação a partir da experiência não tem a ver com técnica ou com prática, mas com arte.

[...] tratei de construir a experiência como uma categoria vazia, livre, como uma espécie de oco ou de intervalo, como uma espécie de interrupção, ou de quebra, ou de surpresa, como uma espécie de ponto cego, como isso que nos acontece quando não sabemos o que nos acontece e sobretudo como isso que, embora nos empenhemos, não podemos fazer com que nos aconteça, porque não depende de nós, nem de nosso saber, nem de nosso poder, nem de nossa vontade (LARROSA, 2015, p. 12).

Portanto, a partir do autor, a experiência é algo que foge ao estabelecido e às tentativas de captura, que podem e se dão por meio de ações educativas mais ou menos abertas e normativas, pelo aprender, cabendo a acepção original de currículo, no sentido daquilo que acontece aos sujeitos enquanto algo acontece.

Segundo o autor, ainda,

(...) insistirei, para terminar, que não se pode pedagogizar, nem didatizar, nem programar, nem produzir a experiência; que a experiência não pode fundamentar nenhuma técnica, nenhuma prática, nenhuma metodologia; que a experiência é algo que pertence aos próprios fundamentos da vida, quando a vida treme, ou se quebra, ou desfalece; e em que a experiência, que não sabemos o que é, às vezes, canta (LARROSA, 2015, p. 13).

Assim, se constroem e reconstroem modos de ser, de saber, de aprender, criativamente, para além dos modelos pré-imaginados, ou seja, se educa e educam-se os outros e a cidade, cotidiana e permanentemente.

Os sentidos - ou o sem sentido - que vão sendo atribuídos àquilo que passa, que se experimenta, constitui-se no saber da experiência, aquilo que adquire consistência, valor e importância a partir do fluxo de sensações, sentimentos, informações que nos chegam e com os quais tomamos contato. Podem vir a ser as marcas do vivido e do sentido, indicando e configurando escolhas, opções, sensibilidades. Esse saber da experiência pode ser socializado, compartilhado, porém é ímpar e pessoal,

\footnotetext{
Um saber que não pode separar-se do indivíduo em quem encarna. [...] Tem sentido no modo como configura uma personalidade, um caráter, uma sensibilidade ou, em definitivo, uma forma humana singular de estar no mundo que é, por sua vez, uma ética (um modo de conduzir-se) e uma estética (um estilo) (LARROSA, 2002, p. 8).
}

O saber da experiência abriga também a abertura para o surgimento do novo, do imprevisível, do não-repetível, do desconhecido, das incertezas. Nas palavras de Larrosa (2002, p. 9), "[...] a experiência não é o caminho até um objetivo previsto, até 
uma meta que se conhece de antemão, mas é uma abertura para o desconhecido, para o que não se pode antecipar, nem pré-ver, nem pré-dizer".

O campo da educação não formal acontecendo no espaço da cidade possibilita o contato com pessoas de diferentes faixas etárias, etnias, gêneros, credos, classes sociais, repertórios simbólicos, espaços, condutas e práticas, ampliando os sentidos, como se o mundo pudesse ser visto, sentido, entendido e significado com outros focos de atenção e disposição, permitindo a possibilidade da criação de algo novo, não como um eterno retorno, mas como um novo início, não como recriação, mas como invenção.

\begin{abstract}
A educação [...] depende da cultura, entendida como texto que se dá a ler e que se nos propõe como algo que nos faz pensar, para inquietar-nos e abrir nossos horizontes de experiências. [...] Se férteis, vida e educação seriam capazes de criar, mais que produzir ou fabricar, não o idêntico, mas o diferente. Por isso, a primeira prova de que a vida e a educação são verdadeiramente humanas é, no fundo, a rebeldia; a 'rebeldia' entendida como essa revolução de que somos capazes as mulheres e os homens que povoamos a Terra quando aceitamos o diferente e fazemos da diferença uma diferença ante o outro. Trata-se da revolução que consiste na capacidade de iniciar algo novo [...], no espaço da pluralidade humana; de romper a cadeia da continuidade, quando [...] somos capazes de renovar o mundo comum com a espontaneidade, com a ação e com a palavra (ORBE, 2001, p. 2 e 9).
\end{abstract}

Para Orbe (2001), a educação que se fascina pela novidade é capaz de fundar o porvir (p. 10).

\title{
METODOLOGIA E DESENVOLVIMENTO
}

Metodologicamente, este é um estudo exploratório, de abordagem qualitativa no campo da Educação, do tipo bibliográfico-documental e descritivo e analítico quanto aos seus objetivos. Parte do levantamento de práticas nacionais brasileiras no campo da educação não formal localizadas na cidade e envolvendo crianças, tendo sido selecionados de um rol amplo, 5 projetos dentro de duas categorias que serviram de base para a discussão dos dados.

Para tentar entender a cidade que mescla educação e cultura, isto é, que forma, que socializa, que humaniza, que subjetiva (CHARLOT, 2010), os dados foram extraídos da Red Ocara uma rede ibero-americana que compila e registra experiências de 12 países da América Latina sobre diversos temas, como: arquitetura, arte, urbanismo, mobilidade urbana, meio ambiente, todos eles centrados na relação entre infância e espaço público.

A rede já realiza o levantamento e o compartilha publicamente, por essa razão optou-se por fazer a seleção a partir da compilação já realizada, selecionando aquelas experiências e práticas que acontecem no Brasil e que envolvem, principalmente, crianças na cidade. Portanto, não foi possível obter depoimentos diretamente dos participantes.

Ao todo, foram selecionadas 24 práticas para efeito de um estudo exploratório. $E$ dentre essas foram selecionados cinco projetos dentro de duas categorias denominadas: a) projetos de revitalização do espaço público e b) projetos de escuta das crianças.

Dentro da categoria projetos de revitalização do espaço público foram selecionadas as seguintes práticas: a) "Quintal", em São Bernardo do Campo², b) "Biourban", em São Paulo $^{3}$ e c) "Parque linear das corujas", em São Paulo 4.

\footnotetext{
Disponível em: <https://www.facebook.com/peetssa/media_set?set=a.10152123532266908.738791907\&type=3>. Acesso em: 13 jul. 2016.

3 Disponivel em: <https://www.facebook.com/media/set/?set=a.576125009137578.1073741829.196814920401924\&type=1>. Acesso em: 13 jul. 2016.

Disponível em: <http://vilaparapequenos.blogspot.com.br/2012/03/parque-das-corujas.html>. Acesso em: 13 jul. 2016.
}

Cad. Pesq., São Luís, v. 25, n. 3, p. 147-166, jul./set. 2018. 
Dentro da categoria projetos de escuta das crianças foram selecionadas as seguintes práticas: d) "Projeto criança pequena em foco", no Rio de Janeiro ${ }^{5}$, e) "Projeto Criança Fala", em São Paulo 6 e f) uma iniciativa da CriaCidade, em São Paulo.

De forma sintética, as principais características de cada projeto são descritas e apresentadas a seguir ao lado de algumas imagens que mostram as práticas das crianças em ação e inter-relação com os pares e com os adultos.

\section{APRESENTAÇÃO DOS DADOS}

\section{Projeto “Quintal”, São Bernardo do Campo-SP}

O projeto "Quintal" visa intervir no espaço público de periferia, colorindo fachadas, revitalizando o território e transformando-o em cinema ao ar livre, em horta comunitária e espaço para ocupação artística e política com a participação das crianças que moram no entorno. Um pedaço do bairro passa a ser entendido como o quintal estendido de todas as casas, lugar de encontro, de brincadeira, de conversa, de discussão, de ação, como mostram as imagens a seguir:

Imagem 1: Horta comunitária

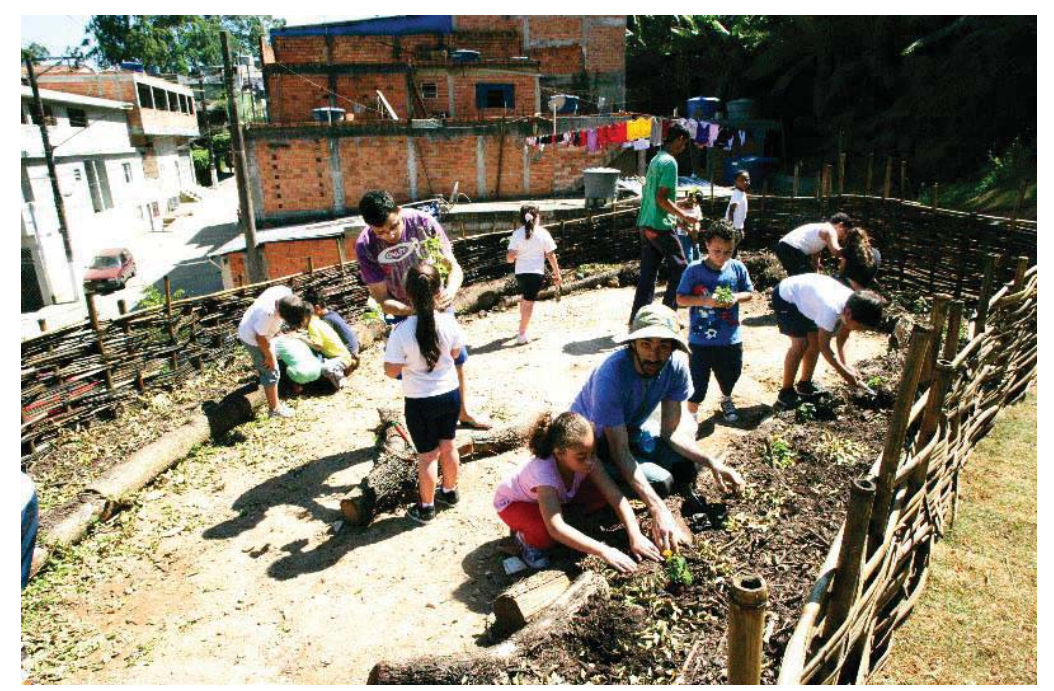

Fonte: Acervo dos autores, s/ano.

Imagem 2: Cabos para brincar

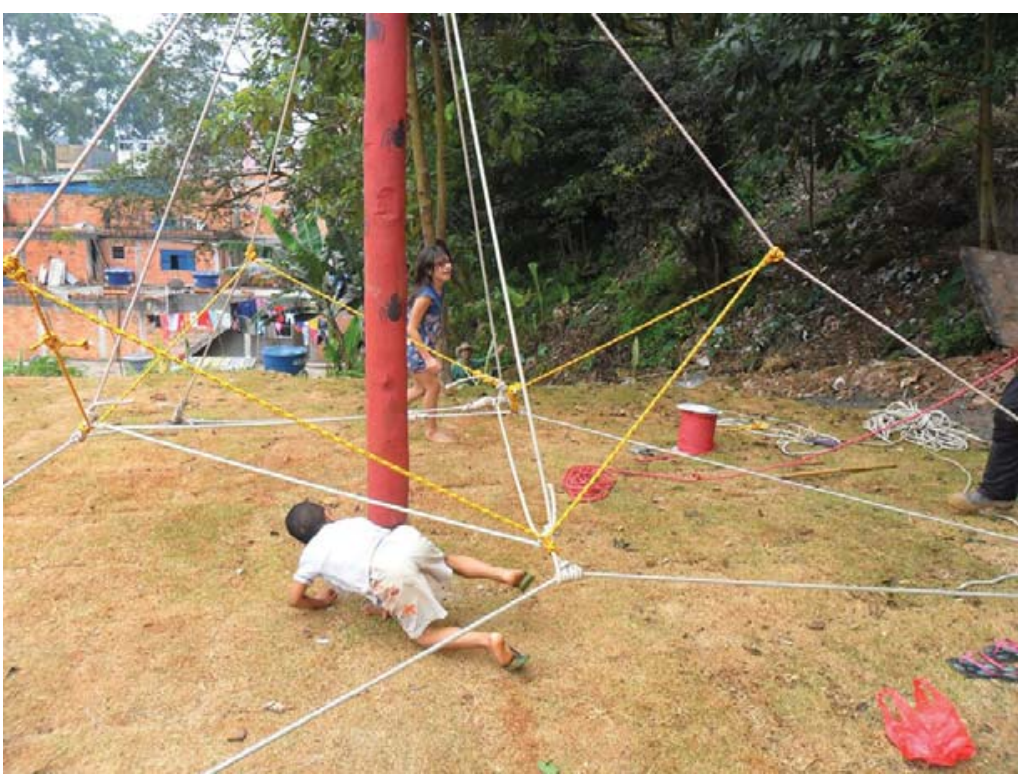

Fonte: Acervo dos autores, s/ano.

Disponível em: http://www.cecip.org.br/site/crianca-pequena-em-foco/. Acesso em: 13 jul. 2016.

6 Disponível em: http://www.criacidade.com.br/. Acesso em: 13 jul. 2016. 
Imagem 3: Preparo do espaço

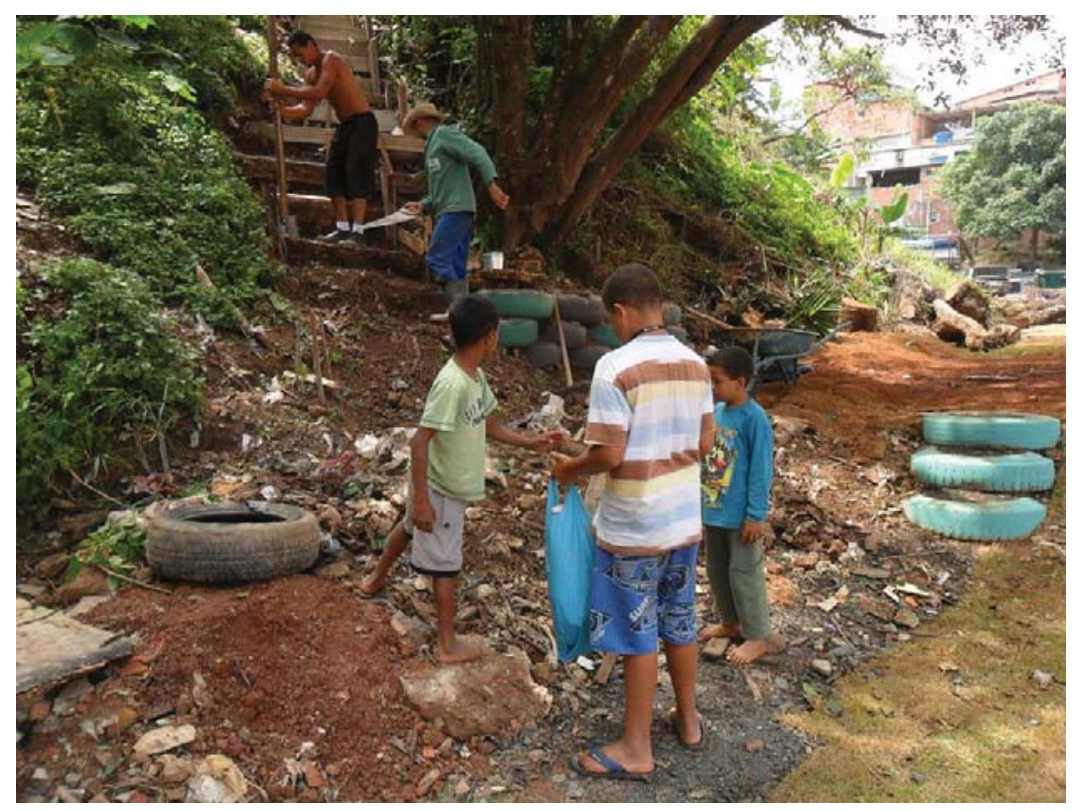

Fonte: Acervo dos autores, s/ano.

As imagens do projeto "Quintal" mostram ações em comunidade nos lugares degradados da cidade, nos espaços indesejados, com topografia acidentada. As crianças aparecem como os grandes interlocutores nas comunidades em que vivem, juntado horta e brinquedos, que estimulam a participação, a colheita e uso das hortaliças e o tempo de brincar, de se socializar, de se divertir.

\section{Projeto "BioUrban", São Paulo-SP}

O projeto "BioUrban" foca na recuperação social e ambiental de espaços públicos degradados, em áreas de risco e vulnerabilidade social. A proposta é fazer a limpeza da frente das casas, criar canteiros de flores, usar cores e materiais reciclados para embelezar as fachadas, abrir espaço para a criação de obras públicas e encenações, oferecer oficinas e atividades artísticas e de reaproveitamento de resíduos e lixo encontrados no bairro. As fotos abaixo mostram alguns episódios das ações sociais e ambientais:

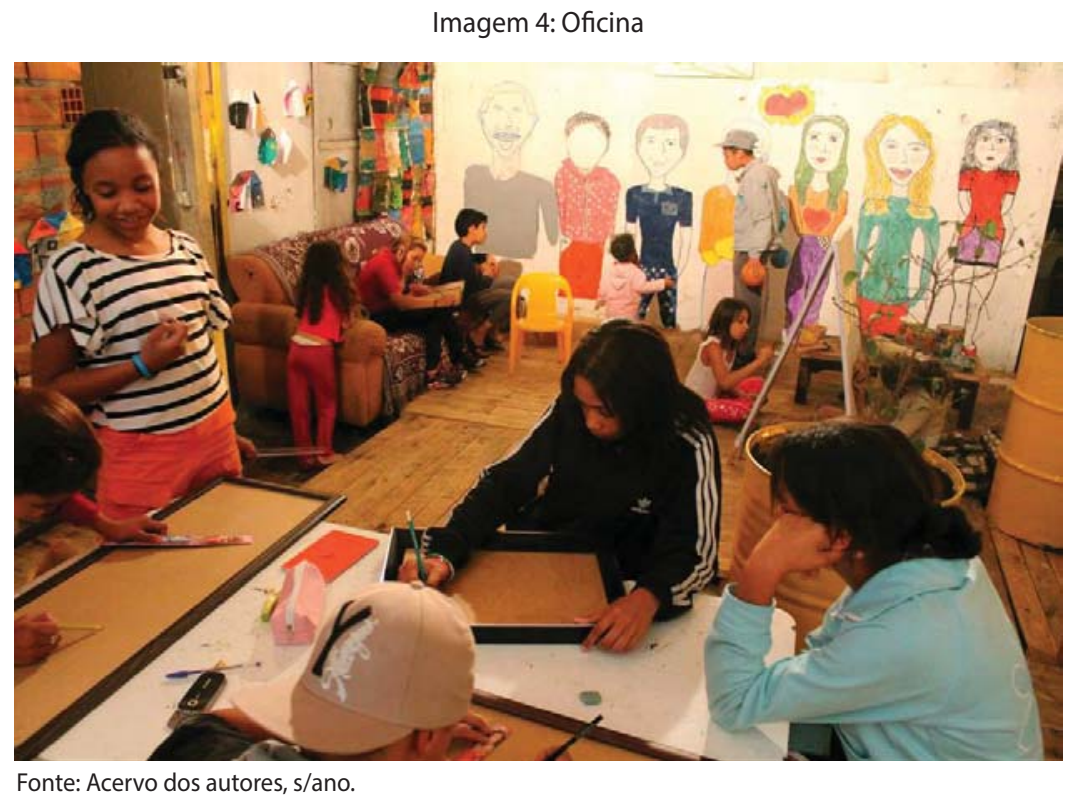


Imagem 5: Oficina

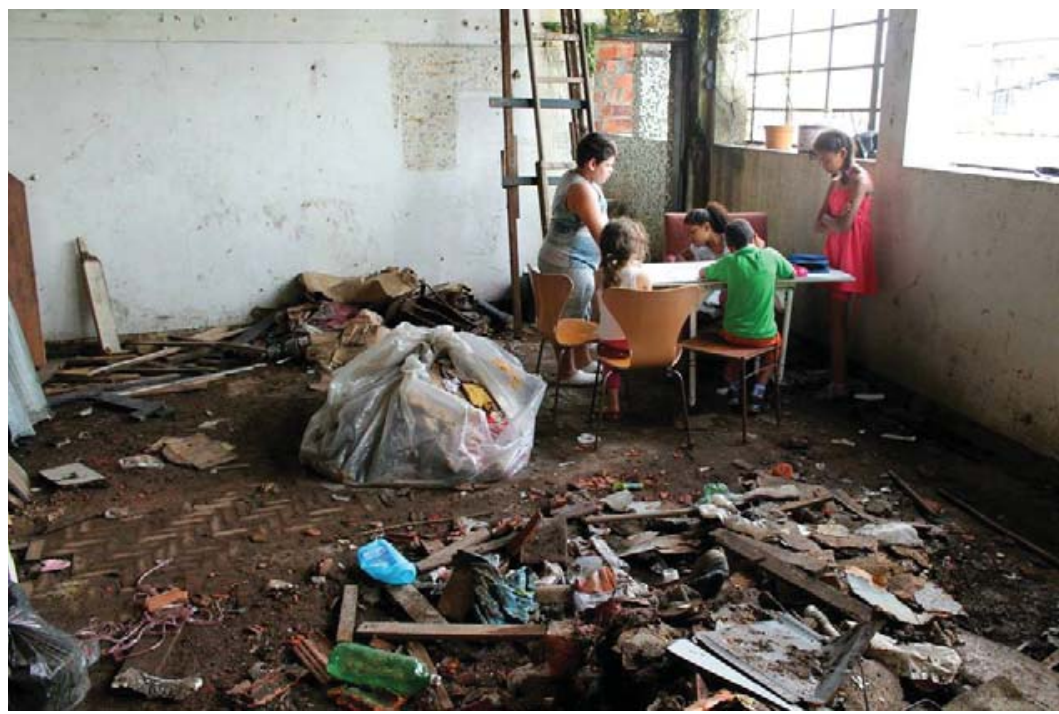

Fonte: Acervo dos autores, s/ano.

Imagem 6: Pintura nas escadarias

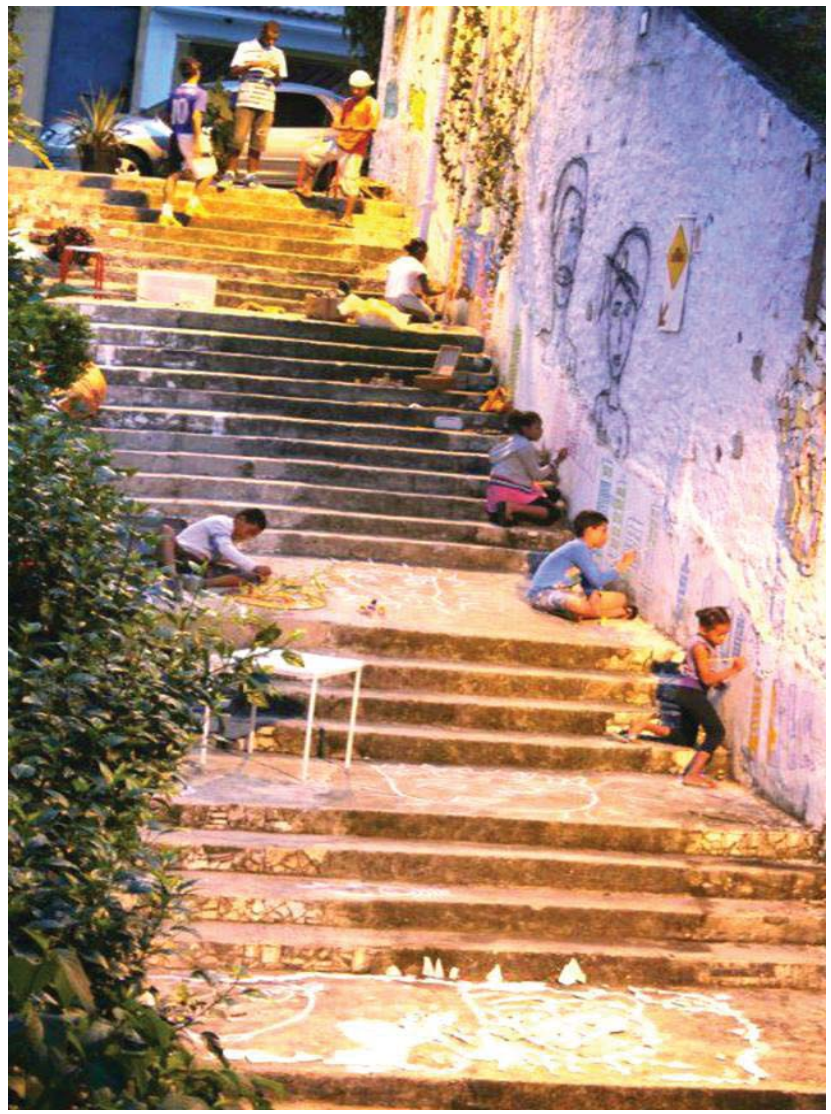

Fonte: Acervo dos autores, s/ano

O projeto "Biourban" coloca a arte como ponte entre a comunidade e a transformação visual onde vivem, por meio de intervenções que trazem para as crianças o sentido de pertença e ocupação simbólica do lugar.

\section{Projeto "Parque linear das corujas", São Paulo-SP}

O projeto "Parque linear das corujas" busca ressignificar o parque cortado pelo córrego das Corujas, em um bairro de classe média. A ideia surgiu dos moradores que queriam melhorar a área degradada, com mato alto e lixo jogado no córrego. A partir de reuniões coletivas foram levantadas as necessidades e vontades da população que centravam-se, basicamente, em torno da mobilidade pedestre, de espaço para lazer 
e atividades públicas e proteção ambiental. Nesse espaço acontecem oficinas com orientação ecológica, como as de permacultura, de orientação artística, como as de stêncil e construções, com orientação social, como piqueniques e reuniões.

As fotos a seguir mostram algumas ações:

Imagem 7: Atividade

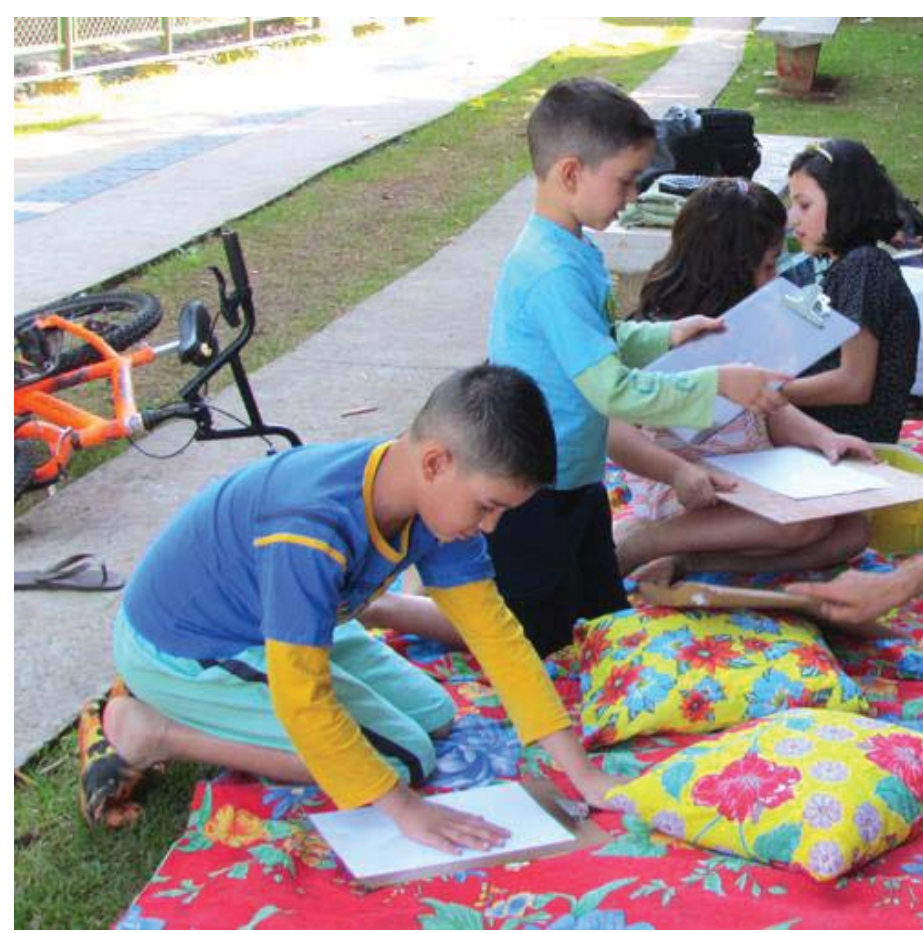

Fonte: Acervo dos autores, s/ano.

Imagem 8: Conversa sobre permacultura

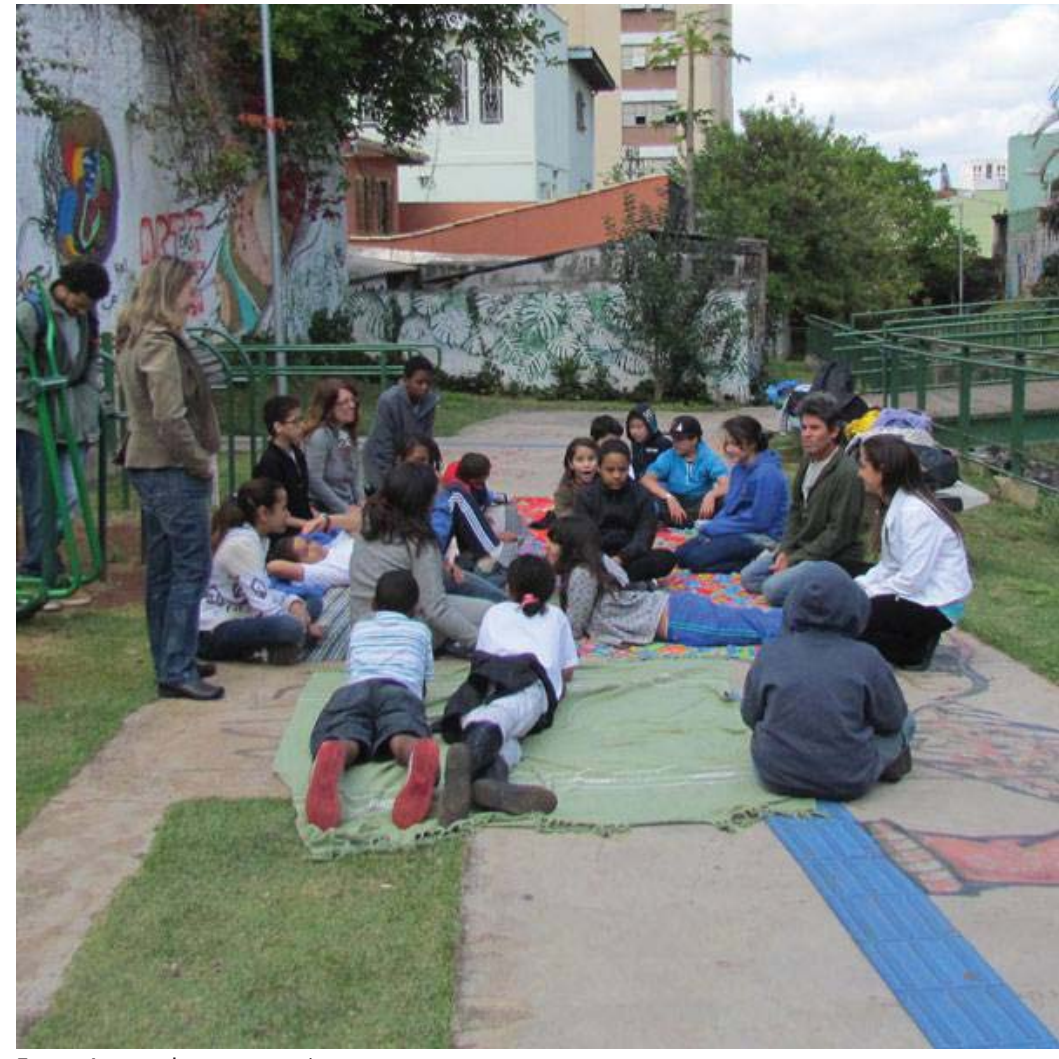

Fonte: Acervo dos autores, s/ano. 


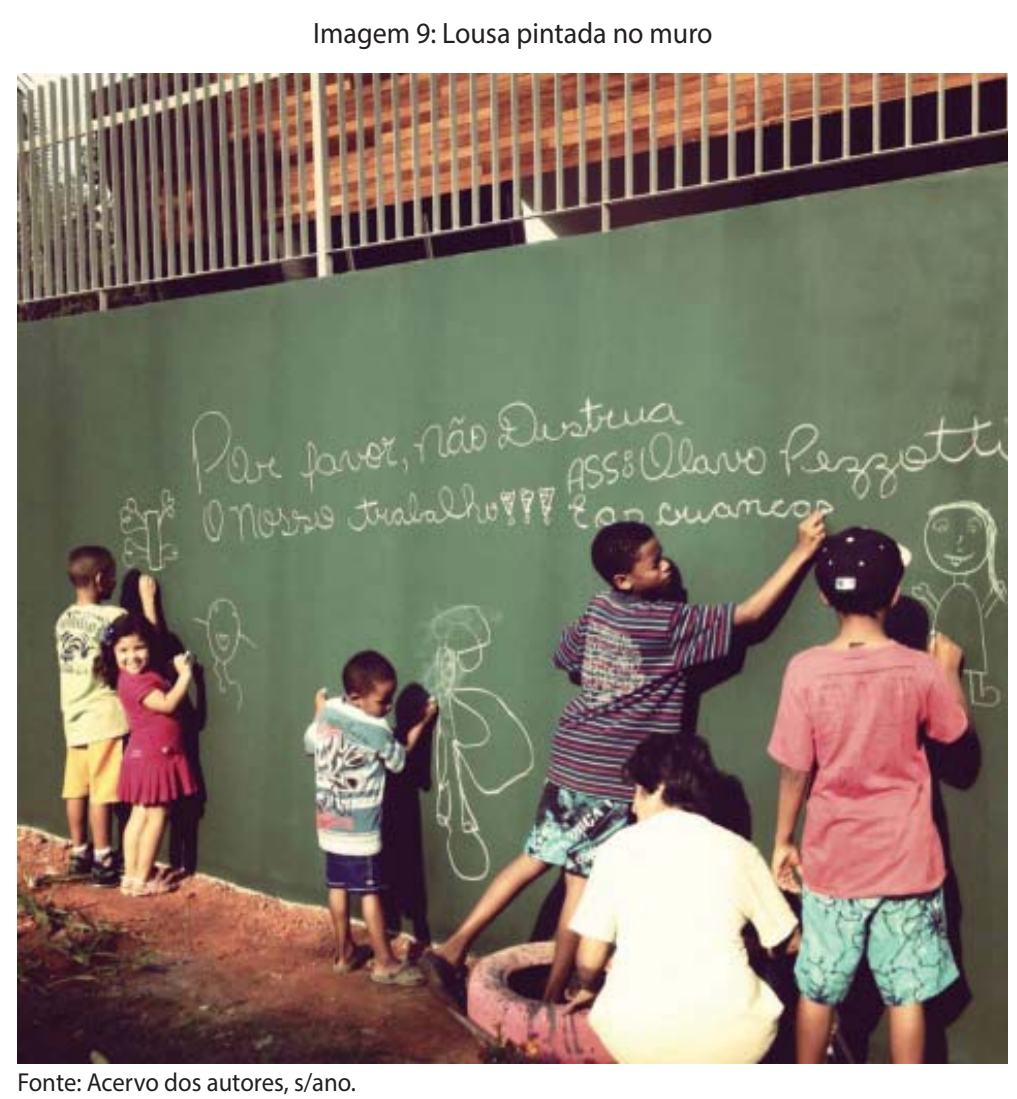

O projeto Parque linear das corujas mostra a ação da comunidade na recuperação, ocupação e participação na transformação e melhoria de espaços públicos degradados.

\section{Projeto "Criança pequena em foco", Rio de Janeiro-RJ}

Dentro da categoria projetos de escuta das crianças, o "Criança pequena em foco" visa saber como as crianças percebem o lugar onde moram, quais suas opiniões sobre os aspectos positivos e negativos e quais mudanças elas gostariam que ocorressem. As crianças pedem parques, arte, bibliotecas, isto é, lazer e cultura e segurança para caminharem pela cidade. A partir desse conhecimento objetiva-se, também, que as falas sirvam de subsídio para as políticas públicas.

O modo de atuação se pauta na realização de ações-piloto com a participação infantil e das comunidades, especialmente, de periferia no planejamento urbano do seu entorno, na realização de seminários, de articulações políticas, na elaboração e divulgação de publicações e nas capacitações de educadores e gestores públicos.

\section{Projeto "Criança Fala", São Paulo-SP}

O projeto "Criança Fala" também se desenvolve por meio de metodologia de escuta infantil, para conhecer o que as crianças querem, pensam, sonham, desejam, suas ideias e necessidades de modo a serem contempladas na elaboração e execução das políticas públicas, nos projetos arquitetônicos, nos projetos políticos pedagógicos e na gestão de espaços e equipamentos sociais.

Os modos de atuação são ações com as crianças e seminários, palestras e oficinas com adultos.

A perspectiva educativa desenvolvida pelos projetos se coaduna com a da educação popular proposta e defendida por Paulo Freire.

De acordo com o Marco de Referência da Educação Popular para as Políticas Públicas (BRASIL, 2014), conceitualmente a educação popular é tratada como prática educativa numa concepção emancipatória e que se vincula a um projeto de sociedade na defesa da transformação da realidade em curso. Logo, ela carrega em si uma dimensão 
política que visa à formação, pela via da socialização, humanização e subjetivação, de sujeitos para uma sociedade mais justa e igualitária, participativa e ativa nas decisões e ações.

A educação popular anseia e trabalha para isto nos meios educativos, tanto no campo da educação formal/escolar como no campo da educação não formal e, neste caso, especialmente pela via das mobilizações coletivas e movimentos sociais que ocupam o espaço público por excelência.

Envolve um percurso metodológico que visa preparar o terreno desde a idealização até as ações sociais e interventivas transformadoras. Tal percurso envolve as seguintes etapas: a) o cenário (a escuta e a voz dos sujeitos dos modos como percebem a realidade e suas problemáticas como ponto de partida), b) espaço de encontro (para estabelecimento de relações e construção de parcerias com diferentes agentes), c) espaço de problematização (envolve a enunciação e reflexão dos fatos e de seus efeitos sociais, políticos, econômicos, culturais, nos modos de viver dos grupos em suas comunidades e na sociedade em geral), d) ação e reflexão (envolve o diálogo ampliado a partir dos saberes de cada sujeito, identificando impasses, contradições, desafios e modos de enfrentamento), e) aprendizagem criativa (envolve processos de construção coletiva de diálogos, de propostas e ações em diferentes níveis de envolvimento com os segmentos da sociedade), f) reinvenção (momento de avaliação dos processos e ações com vistas a revisão e retomada do ciclo metodológico).

Esse percurso que envolve objetivos, estratégias e avaliação faz parte dos modos de ação dos coletivos na cidade. Ele parte de problemáticas identificadas pelos grupos, da escuta das vozes infantis, da participação e da atuação delas como sujeitos sociais e vai sendo construído de modo a ir ao encontro das necessidades e desejos que os grupos dizem ter. Sendo assim, os projetos aqui selecionados operam nos locais em que os grupos sociais escolhidos e as crianças, especialmente, se encontram, seja na periferia ou no centro. Ainda que se possa pensar em possível segregação e não articulação, o foco das ações é fazer com que aconteçam nos lugares de emergência e necessidade primeira.

E ainda, as ações não têm como foco o ensino de algo pré-determinado, mas a aprendizagem que ocorre no encontro e nas conexões entre as pessoas e grupos e seus repertórios culturais.

\section{DISCUSSÃO DOS DADOS}

A partir das descrições dos projetos mencionados, é possível ressaltar a importância e ocorrência de aprendizagens relativas, especialmente, à construção de vínculos de amizade, sentimento de coletividade, o fazer e abertura para o novo. Desta forma, evidenciam-se que os processos e práticas educativas colaboram, de muitos modos, para o desenvolvimento da socialização por meio do engajamento e envolvimento em agrupamentos humanos dos quais se toma parte, da humanização no sentido de imiscuir-se no coletivo como uma força que agrega e reforça laços de pertencimento (ainda que não, necessariamente, de forma harmônica), da subjetivação por meio do exercício de ações contra hegemônicas ou de resistência ao instituído, no espaço urbano, da cidade no contexto capitalista neoliberal.

A importância do fazer pode ser interpretada como um instrumental que potencializa a autonomia e a criação.

O sentimento de coletividade alimenta a necessidade de um sentimento de pertencimento que é base para a construção da identidade. É uma marca de identificação, de reconhecimento. Implica a busca pelo contato, pelo encontro com o outro, pelo risco, pelo inusitado, pelo inesperado, pelo novo. A construção e estabelecimento de relações de amizade acontece por se estar presente em um espaço público e social, que permite a criação de novos vínculos sociais, culturais e emocionais. 
Segundo Ortega (2002), Aristóteles afirmava que,

A consciência de si, a identidade pessoal, se dá através do outro, na contemplação do outro, nossa imagem especular. Na amizade, o indivíduo se faz outro, sai de si, se objetiva; é preciso tomar consciência do pensamento e da atividade do outro para ter consciência do próprio pensamento e da própria atividade [...]. A consciência de si é precedida da consciência do outro, a percepção do amigo é a forma privilegiada da percepção e da consciência de si (p. 41-42).

Em um capítulo intitulado "Amizade na modernidade", Ortega (2002) diz que há um consenso na avaliação da modernidade por Hannah Arendt, Michel Foucault, Richard Sennett, Norbert Elias e Philippe Ȧries, para os quais a amizade "é identificada como um processo de crescente decomposição do espaço público, de privatização e despolitização" (p. 103). Esse processo tem início com o surgimento da família burguesa, que provoca a privatização, despolitização e intimização em seus núcleos.

Diz o autor que,

[...] a família aparece triunfante no século XIX [...]; sendo um mundo em si mesmo, de valor moral mais elevado que o espaço público e, simultaneamente, uma proteção dos terrores da sociedade e da esfera pública. [...] A vida pública, o mundo compartilhado - o espaço de visibilidade para os antigos - tornou-se moralmente inferior diante da felicidade, prometida pela vida burguesa (ORTEGA, 2002, p. 105).

E ele segue:

[...] (na modernidade, a família) tende a se tornar o que nunca havia sido: lugar de refúgio em que se escapa dos olhares de fora, lugar de afetividade em que se estabelecem relações de sentimento entre o casal e os filhos, lugar de atenção à infância. Desenvolvendo novas funções, por um lado ela absorve o indivíduo que recolhe e defende; por outro, separa-se mais nitidamente que antes do espaço público com o qual se comunicava. Estende-se a custa da sociabilidade anônima da rua, da praça (ORTEGA, 2002, p. 106).

Além do que, a rua, representada quase que, unanimemente, no imaginário social, com atributos e características negativas e até perniciosas, fica aquém desse lugar, servindo como local de passeio e circulação, e não mais como local de convívio, solidariedade, sociabilidade e desfrute (BAUMAN, 2009). Embora no imaginário social a imagem da rua, do espaço público da cidade, dos meios urbanos, seja altamente negativa, isso não implica na sua negação, pois a frequência a ela ocorre com maior ou menor restrição, cuidado e atenção e seus usos acabam por envolver modos de intervenção diretas mais ou menos, simbólicas, artísticas, poéticas, violentas.

Ao lado de propor a revitalização do espaço público e a recuperação da atratividade que ele tinha antes da privatização no espaço da família, Ortega (2002), frisando a importância da amizade, sugere que "talvez seja o momento de apostar em outras formas de sociabilidade, tal como a amizade que, não substituindo a família, possam coexistir com ela, e fornecer um apoio material, emocional e cognitivo que permita uma superação solidária dos riscos" (p. 161).

E, assim, exercita-se a fruição, o lúdico, a brincadeira, a diversão, a imaginação, a invenção, a criação, a ousadia, a realização pelas próprias mãos, o sentimento, a reflexão e o engajamento sobre o mundo, sobre o outro e sobre si.

Todas as ações escolhidas ajudam a mostrar como a cidade constrói um currículo cotidianamente e que, por meio dele, os sujeitos e os grupos vão se constituindo a partir das experiências da e na cidade, com peculiaridades, especificidades que vão tomando contorno pelos afetos provocados pelos sentidos, pelos registros da experiência guardados na memória, pelo conteúdo simbólico construído, pelas devolutivas que são feitas à cidade por meio das relações e intervenções sociais e ambientais estabelecidas. 
Deste modo, identidades e sentidos advindos do ser sujeito público na cidade são delineados e retrabalhados a todo o momento e em cada espaço, sem se fechar em si, sem cristalizar-se, sem perenizar-se, pois a cidade é o lócus da diversidade, portanto modos culturais advindos diversidade e diferenciação sociocultural se encontram e se tensionam, colocando em movimento as relações de saber-poder.

O que é posto em prática vai de encontro ao que está estabelecido e que é imposto como negligência ou descaso do poder público estatal, de modo que os grupos se negam ao conformismo ou à espera pela resposta que, muitas vezes, tarda ou nem chega ao local. As reivindicações podem e se dão pela via da legalidade e de defesa dos direitos, mas também são tomadas as rédeas pelos próprios sujeitos e grupos sociais, se contrapondo ao que é determinado e ao que se mantém.

As opções de cada projeto, em cada comunidade, em cada lugar, passam por não esperar do Estado o seu papel de agente, pois que na periferia este costuma estar ausente. Os grupos sociais preferem fazer por si mesmos, com suas próprias mãos e recursos, muitas vezes aproveitando o que há no entorno dos bairros, reciclando e reusando materiais dispensados. Outros projetos estabelecem parcerias com grupos, com fundações e institutos do terceiro setor e/ou fazem uso de financiamento coletivo como a plataforma de arrecadação Catarse - para viabilizar a ocorrência e a manutenção das práticas. De qualquer forma, a ideia que sustenta é que os próprios grupos que fazem uso dos espaços os mantenham, cuidem e os animem com usos participativos e comunitários.

As ações escolhidas acontecem nos bairros mais centrais e mais periféricos das grandes cidades, mas podem acontecer em municípios de quaisquer dimensões, bem como no ambiente rural/campo, ainda que a seleção da pesquisa não contemple esse ambiente, algo a ser estudado em futuras pesquisas.

Nota-se que as intervenções costumam acontecer em espaços denominados comunidades e estão espalhadas pelas cidades, entretanto, menos do que práticas pontuais e fragmentadas, a pulsão é para que se articulem em redes, ainda que não haja um articulador comum. Os pontos potentes vão se tocar e alimentar a constelação, mostrando como é possível fazer acontecer a cidade de baixo para cima, a partir dos sujeitos comuns, de qualquer idade, mas especialmente, pela ação e voz das crianças, produtoras de cultura.

E, mais do que ficar confinado nos seus espaços, a ideia é que a cidade inteira seja permeada por usos variados e diversificados, que se estimulem o convívio e o estabelecimento de relações entre os diferentes e não a manutenção dos iguais, pois que isso estimularia a segregação e não a inclusão.

Cada um dos exemplos apresentados encaixa-se nas três dimensões definidas por Trilla (1999), isto é, aprende-se na cidade, nas instituições e fora delas, tanto das que se organizam educacionalmente (como a escola) como as que são potencialmente educativas, por meio de estratégias e metodologias como passeios, oficinas, cursos em que se aprende diretamente no lugar e com aqueles que têm algo a oferecer. $\mathrm{O}$ conhecimento se faz de forma aberta, flexível e interligada, o que constitui um currículo diferente do escolar.

Ao lado disso, os exemplos mostram agir de acordo com planejamentos de ação e reflexão que embasam a Educação Popular, conforme explicitado anteriormente, seguindo um passo a passo que envolve os saberes, a conscientização, a reflexão, a ação conjunta, a reinvenção que busca a transformação da realidade em alguns ou muitos aspectos.

Também se aprende da cidade por meio da variedade de informações e conteúdos disponíveis, provenientes dos diversos estratos socioeconômicos, geracionais, étnicos, de gênero, a partir de encontros possibilitados pelo convívio e socializações dos grupos pertencentes aos mesmos locais ou que, empaticamente, se somam a esses, que trazem 
em si tensões, contradições, ambiguidades de sentidos e orientações. Participam os que se coadunam e os que passam a coadunar com os propósitos e com o percurso. Neste caso, como diz Trilla (1997), o currículo oculto se visibiliza.

E, por fim, aprende-se a cidade, pois que o conhecimento e os significados dela se ampliam a partir das situações e momentos de experiência direta na cidade, ainda que sejam parciais e superficiais, como diz Trilla (1997), já que é impossível apreender na sua totalidade expansiva e profundidade. Mas sempre é, ao mesmo tempo, conhecimento horizontal e vertical. Da mesma forma, devolvem-se à cidade repertórios e conteúdos reelaborados, retrabalhados de forma simbólica, artística, política e disponibilizados no espaço urbano e para uso e fruição, igualmente, públicos.

Neste sentido, entende-se como a educação e a cultura, áreas de conhecimento e produção indisciplinares, são práticas sociais e participam da construção de identidades e diferenças.

O direito à cidade se faz a partir da participação e da construção cotidiana e coletiva, envolvendo o exercício do sujeito político e do sujeito brincante, que é lúdico por constituição social e cultural.

Habitamos a cidade assim como ela nos habita.

\section{CONCLUSÃO}

Retomando-se o objetivo inicial, neste estudo apresentamos e discutimos aspectos educativos no campo da educação não formal que são desenvolvidos por meio de ações sociais e comunitárias, relacionando com o conceito de currículo e de currículo oculto no universo da cidade.

O currículo existente na cidade e que é experienciado nela, entendendo-a como campo de educação não formal, é o que permite e promove a convivência pública, não a do confinamento no espaço domiciliar ou a do excesso de institucionalização. Ainda que não seja possível garantir que haja experiência, já que esta é singular e pessoal, é possível apostar que ela acontece para alguns e, neste caso, intui-se que, entre tantas possibilidades, deve ter havido a experiência da partilha, da conversa, da comida. $E$, também o contato e a experiência artística com as apresentações musicais, circenses, performáticas e ecológicas, com o trato e cuidado do meio ambiente.

É possível pensar na experiência com o diferente e a diversidade de opiniões, pensamentos, de tomadas de decisões e escolhas coletivas, para o bem comum e não o interesse particular. E na experiência da cogestão e da auto-organização, instâncias do fazer coletivo a serem aprendidas, cotidianamente.

$E$, ainda, é possível suspeitar da experiência na construção do senso de responsabilidade pelo que é público, de todos e não de alguns segmentos isolados ou que se isolam. A possibilidade do sentimento de pertencimento a algo, a algum lugar, a algum tempo, de criar laços. O sentimento de afetividade pela alteridade e a possibilidade de criar e de fazer uso criativo, ou seja, de imaginar outros possíveis.

Enfim, é criar cidades conjuntamente, o que acontece quando se faz em conjunto, pois a força do coletivo traz a força das microações políticas. Apostar nas crianças e disponibilizar escuta para suas vozes, ideias, desejos, urgências e necessidades é fazer das cidades lugares mais inclusivos e com maior qualidade de vida e experiência para todos.

Os processos de organização social e popular representam positivas experiências educativas de formação, de socialização, de humanização, de subjetivação (CHARLOT, 2010), de consciência e organização coletivas que potencializam a luta por direitos e políticas públicas para a área social, se configurando na busca pela transformação da realidade e do mundo a partir de problemáticas do cotidiano e de como os agrupamentos humanos percebem e sentem a realidade e seus efeitos simbólicos e concretos. 
As crianças que participam dos projetos são entendidas como sujeitos sociais e públicos, que consomem e que produzem cultura, promovendo processos de criação, reinvenção e modificação do entorno, do que é comum, das comunidades e da sociedade. Essa participação e as ações empreendidas dão margem a novas possibilidades de atuação no mundo, tirando os sujeitos das tiranias da intimidade.

Reinventam-se discursos e valores, questionam-se aspectos culturais e ideológicos fazendo frente ao que é hegemônico, dominante e legitimado no espaço da cidade, operando resistências. Assim, ao lado de processos de opressão e manipulação pelos quais passam, especialmente, as populações periféricas, empobrecidas, mas ainda, as crianças, como elos mais frágeis na rede social, na malha do Estado, de projetos do terceiro setor e das classes dominantes (presentes nas intencionalidades dos projetos e seus delineamentos), há práticas e processos de criação que seguem em diferentes direções.

O contato com o novo carrega em si o potencial para se romper com o que está estabelecido, trazendo a possibilidade da transformação, pelo uso da imaginação, da criatividade, da criação, da projeção e da realização. Enfim, é no espaço da cidade que é possível e necessário se ensaiar outros modos de ser e de organizar o mundo social e coletivo.

Em síntese, a ideia-força de Trilla, da cidade como campo da educação não formal, se afirma e se valida a partir deste estudo.

\section{REFERÊNCIAS}

BAUMAN, Z. Confiança e medo na cidade. Rio de Janeiro: Jorge Zahar Ed., 2009.

BRASIL. Secretaria Nacional de Articulação Social, Departamento de Educação Popular e Mobilização Cidadã. Marco de referência da educação popular para as políticas públicas, Brasília, 2014. Disponível em: <http://conae2014.mec.gov.br/images/pdf/MarcodeReferencia. pdf>. Acesso em: 26 jul. 2016.

CARNEIRO, H. S. Rebeliões e ocupações de 2011. Apresentação. In: HARVEY, D. et al. (org). Occupy: movimentos de protesto que tomaram as ruas. São Paulo: Boitempo/Carta Maior, 2012, p. 7-14.

CERTEAU, M. de. A invenção do cotidiano. Artes de fazer. Petrópolis: Vozes, 2008.

CHARLOT, B. Desafios da educação na contemporaneidade: reflexões de um pesquisador Entrevista com Bernard Charlot. Educação e Pesquisa, v. 36, n. especial, p. 133-143, 2010.

COMITÊ INVISÍVEL. Aos nossos amigos: crise e insurreição. Rio de Janeiro: N-1 Edições, 2015.

FARIA, A. L. G. de; MELLO, S. A. (orgs). Linguagens infantis: outras formas de leitura. Polêmicas do nosso tempo. Campinas, São Paulo: Autores Associados, 2005.

FERNANDES, R. S. Educação não formal, projetos e o exercício da formação: por uma educação sem bússolas. In: AIDAR, G.; CHIOVATTO, M.; AMARO, D. R. (coords). Entre a ação cultural e a social: museu e educadores em formação. São Paulo: Pinacoteca de São Paulo, 2016, p. 116-139.

GARCIA, V. A. Educação não formal como acontecimento. Holambra: Setembro, 2015.

GOMES, A. C. C.; VIEIRA, L. A. O currículo como instrumento central do processo educativo: uma reflexão etimológica e conceitual. Anais do IX Congresso Nacional de Educação - EDUCERE, III Encontro Sul Brasileiro de Psicopedagogia. PUCPR, Paraná, 2009. 
HARVEY, D. O direito à cidade. Lutas Sociais, São Paulo, n.29, p.73-89, jul./dez. 2012.

LARROSA, J. Tremores: escritos sobre experiência. Belo Horizonte: Autêntica, 2015.

LARROSA, J. Notas sobre a experiência e o saber de experiência. Revista Brasileira de Educação, Rio de Janeiro, n. 19, p. 20-28, abr. 2002. Disponível em: <http://www.scielo.br/scielo. php?script=sci_arttext\&pid=S141324782002000100003\&lng=en\&nrm=iso>. Acesso em: 26 nov. 2018.

LEFEBVRE, H. O direito à cidade. São Paulo: Documentos Itda, 1991.

MESQUITA, A. Insurgências poéticas: arte ativista e ação coletiva. São Paulo: Annablume/ FAPESP, 2011.

MIRANDA, A. C.; FERNANDES, R. S. Educação não formal e a cidade: memórias de infância e perspectivas. Revista de Ciências da Educação, Americana, ano XVI, v. 2, jul-dez, 2014, p. 56-82.

ORBE, F. B. A aprendizagem do novo: reflexões sobre a tragédia no começo, in Leituras SME, Rede Municipal de Educação de Campinas/Fumec, n. 3, julho/2001.

ORTEGA, F. Genealogias da amizade, SP: lluminuras, 2002.

RED OCARA. Disponível em: <http://www.redocara.com/>. Acesso em 05 out. 2017.

ROLNIK, R. As vozes das ruas: as revoltas de junho e suas interpretações. In: MARICATO, Ermínia et al. (org.). Cidades Rebeldes: Passe Livre e as manifestações que tomaram as ruas do Brasil. São Paulo: Boitempo/Carta Maior, 2013, p. 7-14.

SENNETT, R. O Declínio do Homem Público: as tiranias da intimidade. São Paulo: Companhia das Letras, 1988.

SILVA, T. T. da. O currículo como fetiche: a poética e a política do texto curricular. Belo Horizonte: Autêntica, 2010.

SILVA, Tomaz Tadeu da. Documentos de identidade: uma introdução às teorias do currículo. Belo Horizonte: Autêntica, 1999.

TONUCCI, F. La ciudad de los niños: un modo nuevo de pensar la ciudad, Buenos Aires: Losada, 1996.

TRILLA BERNET, J. Ciudades educadoras: bases conceptuales. In M. A. S. ZAINKO (org). Cidades educadoras. Curitiba: UFPR, p. 13-34, 1997.

TRILLA BERNET, J. A educación non formal e a cidade educadora: dúas perspectivas (unha analítica e outra globalizadora) do universo da educación. Revista Galega de Ensino, n. 24, set., p. 199-221, 1999.

VIEIRA, E.; AQUINO, J. G. Sobre a pedagogização da experiência urbana: o projeto da cidade educadora. Educação Unisinos, 19(3), set/dez, 2015, p. 313-324. 